\title{
Layout Planning of Highway Transportation Environment Monitoring Network: The Case of Xinjiang, China
}

\author{
Na Zhang ${ }^{1,2,3}{ }^{\oplus}$, Xianghui Zhao ${ }^{1}$, Tao Liu ${ }^{1, *}$, Ming Lei ${ }^{2, *}$, Cui Wang ${ }^{1}$ and Yikun Wang ${ }^{4}$ \\ 1 Key Laboratory of Highway Engineering Technology in Arid \& Desert Region, Xinjiang Academy of \\ Transportation Sciences, Xinjiang 830000, China; zhangnanuaa@163.com (N.Z.); \\ wupeng1983225@sina.com (X.Z.); wangcui2003@163.com (C.W.) \\ 2 Guanghua School of Management, Peking University, Beijing 100871, China \\ 3 School of Economics and Management, Shihezi University, Shihezi 832000, China \\ 4 Urumqi Environmental Monitoring Center Station, Xinjiang 830000, China; Yikun_wang@163.com \\ * Correspondence: 1_tao2000@163.com (T.L.); mlei508@163.com (M.L.); \\ Tel.: +86-0991-5280483 (T.L.); +86-010-62756243 (M.L.)
}

Received: 4 December 2019; Accepted: 25 December 2019; Published: 30 December 2019

\begin{abstract}
Environmental monitoring is an important tool for environmental protection supervision and management. Environmental monitoring can help us effectively understand and master the degree of environmental pollution, and provide data support for putting forward environmental protection measures. Scientific layout and reasonable level of environmental monitoring network design is an essential cornerstone for environmental monitoring, and a significant measure to promote the industry and green sustainable development. This paper systematically analyzed its requirements of monitoring stations in the highway traffic environment monitoring network. First of all, the paper analyzed the influencing factors of regional monitoring stations in the Xinjiang transportation environment monitoring network by referring to the idea of planning the distribution points of the national transportation environment monitoring network, and determines the weight of them by using the analytic hierarchy process (AHP), which lays a foundation for the subsequent selection and determination of environmental monitoring stations. Secondly, the advantage order of ecological monitoring objects' importance degree was synthetically sorted by the fuzzy comprehensive evaluation method. Finally, the ranking results of the environmental monitoring objects were integrated to determine the number of traffic environmental monitoring stations that need to be built, and the layout of the highway traffic environment monitoring network in Xinjiang was proposed.
\end{abstract}

Keywords: environmental monitoring network; planning layout; highway transportation; fuzzy comprehensive evaluation; AHP

\section{Introduction}

Environmental monitoring data, as an important means to grasp the current situation of the environment and reveal the trend of ecological development, has been an important method for the transportation industry to understand the impact of traffic development on the environment. The Overall Plan for National Highway and Waterway Transportation Environment Monitoring Network, launched by the Chinese Ministry of Transport in 2015, proposed that a transportation environment monitoring network with the characteristics of wide coverage, scientific layout, reasonable level, and smooth joint will be built at the end of 2030, which covers the construction of transport infrastructure, operation process, and passenger and cargo transportation activities. The network is intended to provide factual and reliable data for the transportation sector to monitor environmental 
quality and trends and ultimately make decisions and plans. In the process of highway traffic and transportation environment monitoring, more information can be obtained with the increase of the number of monitoring stations, but it is bound to increase the financial burden of the government due to the increase in the number of monitoring stations [1-4]. In order to improve the effectiveness of highway transportation monitoring, the network covering all kinds of strategic transportation infrastructures should be built. The data from each monitoring station should be analyzed with a scientific and reasonable method, so as to improve the network coverage of space and the representation of the statistical data. The monitoring network layout was optimized under the promise of meeting the needs of traffic industrial environmental monitoring.

Compared with the national environmental monitoring network, the characteristics of the traffic environment monitoring network are reproduced below. Firstly, the monitoring points are more industry-specific. The national ecological monitoring network, based on the administrative divisions and environmental sensitivity, establishes the environmental monitoring network of provinces, autonomous regions, municipalities directly under the central government, as well as cities and counties at various levels. According to the environmental monitoring sensitivity, online monitoring points are set up for vital water systems and environmental protection zones. The traffic environment monitoring network is mainly targeted at the environmentally sensitive areas related to traffic construction, focusing on areas with high highway grade, large traffic volume, and sensitive ecological environment. Construction stations and flow monitoring points of traffic environment monitoring are mostly set within $2 \mathrm{~m}$ away from the highway. Secondly, environmental monitoring indicators of the highway network are more industry-specific. At present, there are greater than 300 environmental monitoring indicators, including water, air, noise, vibration, radiation, and other categories. The traffic environmental monitoring index is mainly directed at the particular pollutants monitored in the transportation construction and operation period, which aims to understand the environmental impact of traffic construction in different periods. In addition, the index irrelevant to the traffic construction will not be followed.

By the end of 2018, the total length of highways in Xinjiang had reached 189,000 km, including $35,600 \mathrm{~km}$ of the Xinjiang Production and Construction Corps, and all regions except Hetian were basically connected with expressways. There were 547 graded passenger stations and 105 freight stations. According to the 13th five-year plan for transport development in the Xinjiang Uygur Autonomous Region, and provincial road planning of the Xinjiang Uygur Autonomous Region (2016-2030), the total size of the highway newly built or rebuilt in Xinjiang reached 153,626 km with a 11,357 km highway, 15,227 km common national and provincial highway, $6767 \mathrm{~km}$ local highway, and 120,276 km rural roads, which is expected to require an investment of 1.085 trillion RMB yuan. With the increase of highway mileage, the impact of highway construction and operation on the atmospheric environment, surface water and groundwater environment, ecological environment and noise is increasingly prominent. Environmental monitoring of the sensitive points and ancillary facilities along the highway can reflect the possible environmental impact and its changing trend in the process of highway construction and operation. But in actual work, the highway transportation environment monitoring site layout is subjective to the decisions of the monitoring department and the monitoring personnel. Monitoring points are generally chosen at random, which has a tendency to ignore the spatial difference of monitoring stations. Therefore, it is necessary for governments to consolidate the existing monitoring network, conduct an overall arrangement of monitoring points, and simultaneously complement the undetected areas.

Considering the characteristics of significant differences in natural environmental conditions among 18 prefectures (cities), Southern Xinjiang, Northern Xinjiang, and Eastern Xinjiang, we aim to clarify the following issues in this paper:

(1) Traffic environment monitoring network is just an organic combination of traffic planning and the environmental monitoring network. How can we create a reasonable and scientific traffic monitoring network evaluation system and measure its importance to the monitoring network? 
(2) The existing monitoring points are subjective and unrepresentative in spatial layout, and unable to effectively provide real-time data of traffic environment monitoring in Xinjiang. How can we screen the traffic environment monitoring points with comprehensive coverage, scientific layout, and at a reasonable level through quantitative methods?

In this paper, the environmental monitoring network of highway traffic and transportation in Xinjiang was mainly planned and set up as ecological monitoring sub-stations, online monitoring points, and mobile monitoring points. In view of state highway mileage and the economic development level, the environmental monitoring sub-stations were set up, and the bus terminals in areas with environmental monitoring sub-stations were equipped with online monitoring points. The analytic hierarchy process (AHP) was used to analyze the weight based on the road grad, traffic flow, and the amount and type of environmentally sensitive indicators along the roads; sequence the importance of environmental monitoring objects in national and provincial highways; and finally, determine the amount of traffic flow monitoring and location.

The rest of this paper is arranged as follows: Section 1 reviews the literature related to our work; Section 2 introduces the relevant research methods, and Section 3 studies the short-term and long-term layout of environmental monitoring sub-stations, online monitoring points, and mobile monitoring points based on the analysis of layout principles. Finally, Section 4 summarizes the concluding opinions.

\section{Literature Review}

Environmental monitoring has been undertaken in many countries, mainly focusing on air quality monitoring [5-14], water or soil environmental quality monitoring [15-20], and marine environmental quality monitoring [21-26]. The literature [4-8] established air pollution monitoring networks respectively covering whole monitoring areas by means of the genetic algorithm (SGA), mixed multiple criteria decision-making (MCDM) theory, geographic information system (GIS), analytic network Process(ANP), and the ordered weighted averaging (OWA) method, and verified the validity of the air pollution monitoring network. The literature [9-14] conducted monitoring and evaluation on-site data by studying low-cost and high-efficiency air quality sensors, and proposed a better selection of sensor location and configuration to improve its accuracy. The literature [15-20] proposed key contents, main monitoring facilities, and monitoring indicators of water or soil resources maintenance monitoring based on the regional natural environment and social and economic characteristics by using methods such as the neural network and genetic algorithm, ArcGIS and clustering analysis, the analytic hierarchy process, and the proximity method. The literature [21-27] analyzed hazardous marine pollutants by using sensors directly applied to contaminated areas of the ocean. They believed that better technology-assisted ocean monitoring and treatment methods could contribute to reducing the spread of pollutants and other illegal activities.

Studies on layout design and optimization algorithm analysis of the ecological monitoring network usually focus on the actual layout requirements, and pay more attention to the detailed setting of monitoring technology, as well as the analysis and use of data after monitoring. The literature [28-39] used GIS, RS, and GAP (A Geographic Approach to Protect Biological Diversity) technology to integrate the existing environmental monitoring network, analyze the point distribution and blank area of the environmental monitoring network, and finally, establish a comprehensive coverage of the environmental monitoring network. Various countries have successively set up and improved upon the diversity of the environmental monitoring system [40-51], such as the long-term ecological research network (LTER Network) [40,41], national ecological monitoring network (NEON) [42], the environmental change network (ECN) [47] environmental monitoring network for India [48], Australian long-term environmental monitoring network [49], and the atmospheric pollution monitoring network at Santiago de Chile [50], as well as the Chinese ecosystem research network (CERN) [51], the Chinese national ecosystem observation research network (CNERN), Chinese forest ecosystem observation research network monitoring stations (CFERN), and marine species. These monitoring networks or monitoring stations are significant national ecological networks which 
constitute an international network for long-term ecological research. These monitoring networks target farmland ecosystems, forest ecosystems, grassland ecosystems, desert ecosystems, wetland ecosystems, and marine ecosystems, which are the main monitoring networks for biological species resources in various countries.

\section{Research Methods}

\subsection{Data Collection}

Through consulting relevant professors and experts from departments of transportation, land, water conservancy, and environmental protection with the Delphi method, it was determined after two rounds of grading demonstration to include the Overall Planning of the National Highway Waterway Transportation Environment Monitoring System, the 13th Five-Year Planning for Xinjiang Uygur Autonomous Region Transportation, and Xinjiang Uygur Autonomous Region Provincial Highway Planning (2016-2030). The data compiled in this paper include the existing road network traffic flow data, existing network service area, toll stations, and the location of the bridges and tunnels. Moreover, environmentally sensitive areas for highway construction are marked, which include nature reserves, scenic spots, forest parks, wetland, and water-source-protected areas.

\subsection{Demand Forecasting Model}

The layout of the Xinjiang transportation environmental monitoring station aims to achieve full coverage of Xinjiang highway environment monitoring, but it should be pointed out that "the whole" here does not mean that the environment monitoring network should cover the 18 prefectures in Xinjiang, but continues the comprehensive analysis according to the importance of the road, traffic, and environmental sensitivity, and finally determines the distribution network. The importance value of the sensitive targets is determined, and environmental monitoring stations are selected by means of the analytic hierarchy process (AHP).

\subsubsection{Determine the Weight of Influencing Factors}

The influencing factors of the regional monitoring station setting include road length, ecological sensitivity, water environment sensitivity, and daily traffic flow. As the main targets of Xinjiang highway transportation environment monitoring network construction are expressway, first-class roads, and second-class roads, the highway mileage here mainly refers to the mileage of highways above the second-class roads (inclusive). Ecological sensitivity index size refers to the area engaged in nature reserves, scenic areas, water environmental conservation, aquatic germ plasm resources, important reservoirs, wetlands, and so on. Sensitivity of water environment mainly refers to the number of surface water source protection areas, spring area protection areas, reservoirs, and so on. The daily traffic volume mainly refers to the daily traffic volume of highways above the second-class level. The weight of the main four indicators is determined by means of AHP.

This paper used the expert consulting method to determine the judgment matrix of each influencing factor, as indicated in Table 1, and calculated the weight of four factors, namely highway mileage, ecological sensitivity, water environment sensitivity, and daily traffic flow.

Table 1. Judgment matrix of influencing factors of traffic environment monitoring layout.

\begin{tabular}{ccccc}
\hline & $\begin{array}{c}\text { Daily } \\
\text { Traffic Flow }\end{array}$ & $\begin{array}{c}\text { Ecological } \\
\text { Sensitivity }\end{array}$ & $\begin{array}{c}\text { Water Environment } \\
\text { Sensitivity }\end{array}$ & $\begin{array}{c}\text { Highway } \\
\text { Mileage }\end{array}$ \\
\hline daily traffic flow & 1 & $1 / 5$ & $1 / 3$ & $1 / 5$ \\
ecological sensitivity & 5 & 1 & 2 & 1 \\
water environment sensitivity & 3 & $1 / 2$ & 1 & $2 / 3$ \\
highway mileage & 5 & 1 & $3 / 2$ & 1 \\
\hline
\end{tabular}


After calculation, the eigenvector of the judgment the matrix $\mathrm{A}$ is $W=(0.0711,0.3727,0.2096,0.3466)$, the maximum eigenvalue of matrix $\mathrm{A}$ is $\lambda_{\max }=4.0080$, and the random consistency ratio is $C R=C I / R I=0.0300<0.10$, indicating that the consistency test of matrix A has passed. Therefore, the obtained eigenvector can be used as the weight of the main environmental monitoring factors. See Table 2.

Table 2. Weight of influencing factors of traffic environment monitoring layout.

\begin{tabular}{ccccc}
\hline $\begin{array}{c}\text { Influencing } \\
\text { Factors }\end{array}$ & $\begin{array}{c}\text { Daily } \\
\text { Traffic Flow }\end{array}$ & $\begin{array}{c}\text { Ecological } \\
\text { Sensitivity }\end{array}$ & $\begin{array}{c}\text { Water Environment } \\
\text { Sensitivity }\end{array}$ & Highway Mileage \\
\hline weight & 0.0711 & 0.3727 & 0.2096 & 0.3466 \\
\hline
\end{tabular}

\subsubsection{Determination of the Value of Influencing Factors}

The influencing factors set by the regional monitoring stations include highway mileage, ecological sensitivity, water environment sensitivity, and daily traffic flow. The values can be obtained through the Statistical Yearbook or calculation.

(1) Highway mileage calculation

Obtained by consulting the Traffic Statistics Yearbook of 18 prefectures.

(2) Ecological sensitivity calculation

Ecologically sensitive areas have certain environmental constraints for highway construction. In order to distinguish the degree to which highway construction is restricted by ecologically sensitive areas, the sensitivity index of ecologically sensitive areas is used in this report to determine the degree to which each road section is restricted by ecologically sensitive areas. The sensitivity degree of ecologically sensitive areas in the region is calculated by the following equation:

$$
R_{R}=\sum_{j=1}^{4} \sum_{k=1}^{4} \xi_{j k}
$$

where $R_{R}$ represents the regional nature reserve sensitivity index, and $\xi_{j k}$ is the influence $k$ degree index of the $j$ grade ecological sensitive area, $j=1,2,3,4 ; k=1,2,3,4$.

(3) Water environment sensitivity calculation

The sensitivity index of the water environment is a measure of whether that highway crosses or is adjacent to the surface water source reserve, a water or regional reserve of more than three kinds of functions, and so forth. We regard those highways covering surface water source reserves, Class I and Class II waters, and key spring water reserve areas as highly sensitive areas; and those highways covering Class III waters, common spring water reserve areas as moderate sensitive areas, and those highways not covering those areas as general areas. A value is assigned to each type of area.

(4) Calculation of daily traffic flow

Obtained by consulting the Traffic Statistics Yearbook of 18 prefectures.

3.2.3. The Primary and Secondary Order of the Monitoring Objects Is Determined by the Comprehensive Evaluation Method of Multi-Objective Fuzzy Index Weight

This paper sequences the importance of monitoring objects highway mileage, ecological sensitivity, sensitivity of the water environment, and daily traffic. Sorting results are integrated to determine the final need to build environmental monitoring sub-stations and the number of online monitoring, and finally conduct the phased construction. 
After the selection was completed, field investigation was carried out to further determine the specific location of the Xinjiang traffic road network.

\section{Results}

\subsection{Layout Principles}

4.1.1. Principles of Layout of Environmental Monitoring Sub-Stations and Online Monitoring Points

The layout of environmental monitoring sub-stations and online monitoring points needs to meet the following principles based on the environmental impact of transport infrastructure construction, operation scope and degree, and the nature of rationality, uniformity, and the representative.

(1) Fully consider the length of state (city) highways.

(2) The node capacity of different prefectural status is quantified by comprehensively considering the economic development level and passenger and cargo volume.

(3) Analyze the traffic location built on the current situation of urban traffic resources in various prefectures (cities) and the degree of traffic correlation with other regions.

(4) Prefectures (cities) with extensive expressway mileage, high node capacity, and important traffic location should be prioritized.

\subsubsection{Principles of Layout of Mobile Monitoring Points}

The selection of mobile monitoring sites should be representative and scientific. According to the current situation of the ecological environment in Xinjiang and the environmentally sensitive targets, regular and periodic monitoring should be carried out throughout Xinjiang. The layout of monitoring sites should comply with the following principles.

(1) Different types and intensity of traffic activity brings pollution emission intensity, so the key highway environment monitoring objects is the expressway with the daily traffic volume of more than 10,000 vehicles (passenger car equivalent standard), and the common highway with the daily traffic volume of more than 5000 vehicles (passenger car equivalent standard).

(2) Key environmental monitoring objects of the expressway include service areas with a daily traffic volume of over 9500 units (equivalent standard passenger cars) and toll booths with daily traffic volume of over 14,000 units (equivalent standard passenger cars).

(3) Monitoring points should be arranged in tunnels longer than $1000 \mathrm{~m}$.

(4) Bridges are crucial to the protection of water bodies. For bridges longer than $1500 \mathrm{~m}$, monitoring points should be established in the water bodies they cross.

(5) Different types of environmental impact objects have different impact characteristics, elements, and degrees, so they should be selected according to the environmental influence objects.

(6) There should be a focus on national and provincial nature reserves, scenic spots, important wetlands, important reservoirs, forest parks, protection areas of important drinking water sources, and highways mainly crossing (or adjacent) the above-mentioned confidential protection targets.

(7) Comprehensive consideration should be given to highway traffic volume and environment-sensitive targets, and representative flow monitoring points should be selected.

(8) The selection of ambulatory monitoring points should cover the whole territory of Xinjiang and take medium and long-term road planning into consideration.

Construction of mobile environmental monitoring sites in Xinjiang uses the analytic hierarchy process (AHP) to assign the weight onto the highway level, travel traffic and environmentally sensitive factors, and sequence the important and rank the integrated results of environmental monitoring objects. 


\subsection{Layout Planning of Environmental Monitoring Sub-Stations and Online Monitoring Points}

Node capacity is a comprehensive reflection of various interrelated factors, such as the level of economic and social development and the amount of transportation. Traffic location reflects the condition of urban traffic resources and the degree of traffic correlation with other areas. The highway transportation hub city should have specified node capacity and special traffic location conditions. According to the National Highway Transport Hub Layout Planning, seven transportation hubs are selected, namely, Urumqi, Hami, Korla, Kashi, Shihezi, Kuitun, and Yining (Huoerguosi), to support economic and social development, safeguard national security, and serve sustainable development. These seven hub cities cover the entire region of Xinjiang and are very representative. Moreover, passenger and freight stations are an important node that can reflect the operational capacity of road transport hubs and the status quo of the polluted environment. Therefore, online monitoring points are set up in seven passengers and freight stations where road transport hubs are located. In view of the fact that the Urumqi environment monitoring center and Yili environmental monitoring sub-station have been built at the beginning of the 12th five-year planning, four more environmental monitoring substations and online monitoring passenger and freight stations will be built during the periods of the 13th five-year plan and the 15th five-year plan.

\subsection{Determination of Mobile Traffic Environment Monitoring Points}

\subsubsection{Evaluation Index System for the Importance of Environmental Monitoring Objects}

The key factors to determine the main mobile provincial expressway points are road grade, traffic flow, the types of protected areas, protection level, and the distance between the highway and the monitoring object. The space analysis method (namely, superimposed) was used to determine the adjacent relationship between the national and provincial highways and such environmentally sensitive areas as nature reserves, wetlands, forest parks, scenic spots, centralized surface water sources, and reservoirs.

Mobile monitoring objects for those environmental monitoring objects were selected according to the comprehensive evaluation of the importance degree. The analytic hierarchy process (AHP) was used to screen out the environmental monitoring sensitive points [52]. The higher the score, the greater the significance of these monitoring points to the whole monitoring process. In this way, the monitoring points with a big influence on traffic and high environmental sensitivity were selected as the final mobile monitoring points.

The index of importance of environmental monitoring objects was used to characterize the selection of mobile environmental monitoring points, and the importance of highway and environmental monitoring was selected for quantitative research. The specific calculation model is as follows [53]:

$$
Z=\sum_{i=1}^{n}\left(a_{i} A_{i}\right)
$$

where, $Z$ represents the importance of environmental monitoring objects; $a_{i}$ is the weight of the $i$ th index, which can be obtained by means of the expert scoring method or brainstorming method; $A_{i}$ is the $i$ th index value of the monitoring object; and $n$ represents the number of indicators.

The importance of environmental monitoring objects was calculated by using AHP combined with multi-stage fuzzy comprehensive evaluation.

Taking the importance of environmental monitoring objects as the target level, the two factors that affect the importance of environmental monitoring objects are the importance of the highway and the importance of environmentally sensitive targets. Environmentally sensitive target indicators include nature reserves, scenic spots, important wetlands, water source protection areas, aquatic germ plasm resources protection areas, and so forth. Environmentally sensitive target protection levels and their distance from the highway were used to determine the necessity of environmental monitoring objects. 
The highway grade index mainly refers to the level of the highway involved, including expressways, first-class highways, second-class highways, and third-class highways. Environmentally sensitive target type indicators mainly refers to the highway's environmentally sensitive target type, including wetland nature reserves (national and autonomous regions), wetlands (national and autonomous regions), forest parks (national and autonomous regions), scenic areas (national and autonomous regions), the centralized surface water sources (first-class water source, second-class water source), and reservoirs. Protection level indicators referred for environmentally sensitive target protection levels consist of three levels. Three levels of aquatic germ plasm resources, nature reserves, and scenic areas correspond to the national, provincial, and municipal levels, respectively. The three levels of water source reserves correspond to first- and second-class water, third-class water, and water below the third class. The relationship between the highway and environmentally sensitive targets can be divided into crossing the protected area, being adjacent to protected area (distance $<200 \mathrm{~m}$ ), and being adjacent to the sensitive area (distance $>200 \mathrm{~m}$ ). See Table 3 .

Table 3. Evaluation index system of the importance of environmental monitoring objects.

\begin{tabular}{|c|c|c|c|}
\hline Target Level & First Level & Second Level & Third Level \\
\hline \multirow{5}{*}{$\begin{array}{l}\text { The importance of } \\
\text { environmental } \\
\text { monitoring objects }\end{array}$} & \multirow{2}{*}{$\begin{array}{l}\text { The importance } \\
\text { of the highway }\end{array}$} & The level of the highway & $\begin{array}{l}\text { expressways } \\
\text { first-class highways } \\
\text { second-class highways } \\
\text { third-class highways }\end{array}$ \\
\hline & & The traffic flow & $\begin{array}{c}>15,000 \text { vehicles/day } \\
10,000-150,000 \text { vehicles/day } \\
5000-10,000 \text { vehicles/day }\end{array}$ \\
\hline & \multirow{3}{*}{$\begin{array}{l}\text { The importance } \\
\text { of environmental } \\
\text { sensitive }\end{array}$} & $\begin{array}{c}\text { The environmentally } \\
\text { sensitive }\end{array}$ & $\begin{array}{c}\text { water source protection areas } \\
\text { nature reserves } \\
\text { scenic spots } \\
\text { important wetlands }\end{array}$ \\
\hline & & The protection level & $\begin{array}{l}\text { first-class } \\
\text { second-class } \\
\text { third-class }\end{array}$ \\
\hline & & $\begin{array}{l}\text { The relationship between } \\
\text { highway and } \\
\text { environmentally sensitive }\end{array}$ & $\begin{array}{c}\text { crossing protected area } \\
\text { adjacent protected area (distance } \\
<200 \mathrm{~m}) \\
\text { adjacent to sensitive area } \\
(\text { distance }>200 \mathrm{~m})\end{array}$ \\
\hline
\end{tabular}

The evaluation index system of the importance of environmental monitoring objects is composed of two first-level indicators and five second-level indicators, which can be divided into five importance evaluation levels according to the semantic scale: very important, relatively important, generally important, unimportant, and very unimportant. In order to facilitate the calculation, the semantic scale of subjective evaluation was quantified and successively assigned to $5,4,3,2$, and 1 . Subjective measurement is based on the five-level semantic scale. The designed evaluation quantity and membership standards is shown in Table 4.

Table 4. Quantitative grading standards of evaluation grade.

\begin{tabular}{ccc}
\hline Evaluation $x_{i}$ & Membership $\alpha$ & Semantic Scale \\
\hline$x_{i}>4.5$ & $\alpha>0.3000$ & very important \\
$3.5<x_{i} \leq 4.5$ & $0.2333<\alpha \leq 0.3000$ & relatively important \\
$2.5<x_{i} \leq 3.5$ & $0.1667<\alpha \leq 0.2333$ & generally important \\
$2<x_{i} \leq 2.5$ & $0.1333<\alpha \leq 0.1667$ & unimportant \\
$x_{i} \leq 2$ & $\alpha \leq 0.1333$ & very unimportant \\
\hline
\end{tabular}


The weight of each index of the important degree of the monitoring objects was determined by the AHP method, and the results were as follows:

(1) The weight vector of highway importance is $(0.5,0.5)$.

(2) The important vector of environmental monitoring objects is $(0.5278,0.3325,0.1396)$.

(3) The important vector of monitored objects is $(0.3333,0.6667)$.

After the consistency test, the consistency test index value of the highway important degree was $0.0088<0.1$, and the consistency test index value of the environmentally sensitive target was $0.0516<$ 0.1 , indicating that the AHP results have satisfactory consistency and the weight is reasonable. Specific weight results are shown in Table 5.

Table 5. Weights of the importance of monitored objects.

\begin{tabular}{|c|c|c|c|c|}
\hline Target Level & Second-Level & Weight & Indicator Level & Weight \\
\hline \multirow[b]{2}{*}{$\begin{array}{l}\text { The importance of } \\
\text { monitoring objects }\end{array}$} & The importance of highways & 0.3333 & $\begin{array}{l}\text { Highway level } \\
\text { Traffic }\end{array}$ & $\begin{array}{l}0.5 \\
0.5\end{array}$ \\
\hline & $\begin{array}{l}\text { The importance of environment } \\
\text { monitoring objects }\end{array}$ & 0.6667 & $\begin{array}{c}\text { Protection type } \\
\text { Protection level } \\
\text { Distance from highway to } \\
\text { monitoring objects }\end{array}$ & $\begin{array}{l}0.5278 \\
0.3325 \\
0.1396\end{array}$ \\
\hline
\end{tabular}

\subsubsection{Priority Order of the Importance of Environmental Monitoring Objects}

In order to ensure the objectivity of the selection results, this paper carried on the comprehensive sequencing by means of the multi-objective fuzzy index weight based on the four factors of the highway mileage, ecological sensitivity and sensitivity of the water environment, and daily traffic. The number of online monitoring points were determined according to the sequencing results, and can be built with the guidance of the phased construction principle.

The multi-objective fuzzy comprehensive evaluation method is a method that uses the principle of fuzzy relation synthesis to comprehensively evaluate the subordinate status of the evaluated objects from multiple factors and determine the dominant order of multiple objects [54].

The steps of multi-objective fuzzy comprehensive evaluation are as follows:

The first step is to determine the evaluation object's factor domain, $U$, which is $U=\left\{u_{1}, u_{2}, \ldots, u_{n}\right\}$.

The second step is to determine the evaluation rating field $V=\left\{v_{1}, v_{2}, \ldots, v_{m}\right\}$, such as the environmental protection effect $V=$ \{very important, relatively important, generally important, unimportant, very unimportant\};

The third step is to make a single factor evaluation and establish the fuzzy relation matrix $R$, which is:

$$
R=\left[\begin{array}{cccc}
r_{11} & r_{12} & \ldots & r_{1 m} \\
r_{21} & r_{22} & \ldots & r_{2 m} \\
\ldots & \ldots & \ldots & \ldots \\
r_{n 1} & r_{n 2} & \ldots & r_{n m}
\end{array}\right] \quad\left(0 \leq r_{i j} \leq 1\right)
$$

where $r_{i j}$ is the membership relationship between factor $u_{i}$ in $U$ and grade $v_{j}$ in $V$.

The fourth step is to determine the weight vector of evaluation factors $A=\left\{a_{1}, a_{2}, \ldots, a_{n}\right\} . A$ is the subordination relationship of each factor in $U$ to the evaluated thing.

The fifth step is to select the evaluation mathematical model (called synthesis operator) and synthesize $A$ and $R$ as $B=\left\{b_{1}, b_{2}, \ldots, b_{m}\right\}$.

$$
B=A \cdot R=\left(a_{1}, a_{2}, \ldots, a_{n}\right)\left[\begin{array}{cccc}
r_{11} & r_{12} & \ldots & r_{1 m} \\
r_{21} & r_{22} & \ldots & r_{2 m} \\
\ldots & \ldots & \ldots & \ldots \\
r_{n 1} & r_{n 2} & \ldots & r_{n m}
\end{array}\right]
$$


The sixth step is to analyze and process the fuzzy comprehensive evaluation result $B$.

The seventh step is to quantify the fuzzy comments, calculate the importance of each environmental monitoring object, and conduct sorting and screening.

The index membership degree of the highway importance index (highway grade and traffic flow) and environmental test object importance index (protection type, protection level, and distance from the test object) was obtained mainly through expert consultation.

The membership results of highway grade indicators are shown in Table 6:

Table 6. Membership degree of highway grade indicators.

\begin{tabular}{ccc}
\hline Highway Grade & Index Score & Nominalization \\
\hline Expressway & 13 & 0.565 \\
National highway & 7 & 0.304 \\
Provincial highway & 3 & 0.130 \\
\hline
\end{tabular}

The membership degree of traffic flow is as shown in Table 7 :

Table 7. Membership degree of traffic flow.

\begin{tabular}{ccc}
\hline Traffic Flow & Index Score & Nominalization \\
\hline $0-5000$ & 1 & 0.1667 \\
$5000-10,000$ & 2 & 0.3333 \\
$>10,000$ & 3 & 0.5 \\
\hline
\end{tabular}

The membership degree of protection zone type index of environmental detection objects is shown in Table 8:

Table 8. Membership degree of protection zone type index of environmental detection. objects.

\begin{tabular}{ccc}
\hline Protection Area Type & Index Score & Nominalization \\
\hline Nature reserve & 10 & 0.3448 \\
Scenic spots & 6 & 0.2069 \\
The rivers & 5 & 0.1724 \\
Reservoirs & 4 & 0.1379 \\
Wetlands & 4 & 0.1379 \\
\hline
\end{tabular}

The environmental detection object protection level index membership index is as shown in Table 9:

Table 9. Membership degree of environmental detection object protection level index.

\begin{tabular}{cccc}
\hline \multirow{2}{*}{ Protection Area Type } & Index Score & Nominalization \\
\hline \multirow{3}{*}{ Nature reserve } & National level & 10 & 0.5556 \\
& Provincial level & 6 & 0.3333 \\
& Others & 2 & 0.1111 \\
\hline \multirow{3}{*}{ Scenic spots } & National level & 10 & 0.5556 \\
& Provincial level & 6 & 0.3333 \\
& Others & 2 & 0.1111 \\
\hline \multirow{2}{*}{ Rivers } & Major rivers & 8 & 0.7273 \\
& Others & 3 & 0.2723 \\
\hline \multirow{2}{*}{ Reservoirs } & Important reservoirs & 8 & 0.7273 \\
& Others & 3 & 0.2723 \\
\hline \multirow{2}{*}{ Wetlands } & Important wetlands & 7 & 0.5833 \\
& Others & 5 & 0.4167 \\
\hline
\end{tabular}


The membership index of the distance between highways and monitoring objects is as shown in Table 10:

Table 10. The membership index of the distance between highways and monitoring objects.

\begin{tabular}{ccc}
\hline The Distance between Highways and Monitoring Objects & Index Score & Nominalization \\
\hline Crossing & 8 & 0.4444 \\
adjacent protected area (distance $<200 \mathrm{~m}$ ) & 6 & 0.3333 \\
and adjacent to sensitive area (distance $>200 \mathrm{~m}$ ) & 4 & 0.2222 \\
\hline
\end{tabular}

4.3.3. Weight Calculation of the Importance of Mobile Environment Monitoring Objects (or Environmentally Sensitive Areas)

The highway network gram should be superimposed with the gram of various environmentally sensitive elements, and the monitoring points should be screened out. The expert scoring method was used to determine the index membership degree and the important degree of ecological monitoring objects. The weight and ranking of the importance of the mobile environment monitoring objects are presented in Tables 11-15. According to the set degree of importance and membership of environmental monitoring objects, the monitoring objects of the importance degree of more than 0.3000 , namely, categorized as "very important", are taken as the monitoring points.

\section{(1) Nature reserves}

Taking the nature reserve as the monitoring object, the road network map and the distribution map of the nature reserve were superimposed, and nine monitoring points were selected. According to the set degree of importance of the environmental monitoring object, the nature reserve that belongs to the category " $>0.3000$ ", that is, "more than very important", was determined as the monitoring objective of this plan. According to the importance value of the nature reserve environment monitoring objects, eight nature reserves were screened as the monitoring objects of the Xinjiang environmental monitoring network, which include the Huocheng four-claw tortoises nature reserve, Bayinbuk national nature reserve, Luobupo wild camels national nature reserve, Xinjiang Burgen beavers national nature reserve, Kanas national nature reserve, Xinjiang Tianchi Bogda peak nature reserve, Kalamely ungulated wildlife reserve, and Tashkurgan wildlife reserve, as is seen in Table 11.

\section{(2) Scenic spots}

Superimposing the scenic area distribution map and network diagram, six monitoring stations were selected. According to the membership degree of the importance degree of the set environmental monitoring objects, the monitoring objects were selected with an importance more than 0.3000 , that is, belonging to the category of "very important". Two scenic spots were screened as the monitoring objects of the environmental monitoring network, which included the Selimu lake scenic area and Tianshan Tianchi scenic spot, as shown in Table 12.

\section{(3) Wetland parks}

Superimposing the key wetland parks map and network diagram, eight monitoring points were selected. According to the membership degree of the importance degree of the set environmental monitoring objects, the monitoring objects with an importance more than 0.3000 , that is, belonging to the category of "very important", were selected. Four key wetlands and wetland parks were screened as the monitoring objects of the environmental monitoring network, which included the Urumqi river wetland, Aletai Wuqilik wetland park, Selimu lake wetland, and Talimu river Weili wetland, the latter two of which were monitored together. Therefore, there were three wetland parks in total, as shown in Table 13.

\section{(4) Rivers}


Superimposing the river distribution map and network diagram, 31 monitoring points were selected. According to the membership degree of the importance degree of the set environmental monitoring objects, the monitoring objects with an importance of more than 0.3000 , that is, belonging to the category of "very important", were selected. Eight key river areas were screened as the monitoring objects of the environmental monitoring network, which included the Yerqiang river, Urumqi river, Erqisi river, Akesu river, Kongque river, Wulungu river, Talimu river, Hutubi river, and Hetian river, of which the Urumqi wetland and Urumqi river were monitored together. Therefore, there were eight river areas in total, as shown in Table 14.

\section{(5) Reservoirs}

Superimposing the reservoirs distribution map and network diagram, 18 monitoring points were selected. According to the membership degree of the importance degree of the set of environmental monitoring objects, the monitoring objects with an importance of more than 0.3000 , that is, belonging to the category of "very important", were selected. Seven reservoirs were screened as the monitoring objects of the environmental monitoring network, which includes the Tukeyi reservoir, Qiala reservoir, Aweitan reservoir, Jiahezi reservoir, Duolangshui reservoir, and Kelabashi reservoir, as shown in Table 15.

\section{(6) Toll stations}

The toll stations with a traffic flow of over 15,000 vehicles per day were selected as the monitoring objects, which resulted in 15 toll stations being selected, including the Xiaocaohu toll station, Chaiwopu toll station, Wulabo toll station, Toutunhe toll station, Changji toll station, Manasi toll station, Wulanwusu toll station, Shawan toll station, Anjihai toll station, Manasi ramp toll station, 27 regiment toll station, Tashidian toll station, Kuerle toll station, Kuitun toll station, and Sikeshu toll station.

\section{(7) Service areas}

The service areas with a traffic flow of over 9500 vehicles per day were selected as the monitoring objects, which resulted in 15 toll stations being selected, including the Xiaocaohu service area, Yanhu service area, Sanping service area, Tuyugou service area, Fukang service area, Shihezi service area, Wugongtai service area, Yanqi service area, Kuitun service area, Yuqunweng service area, Luotuoquanzi service area, Hami service area, Wuqia service area, Xingxingxia service area, and Jiamu service area.

\section{(8) Bridges}

The bridges with a length of more than $1500 \mathrm{~m}$ were selected as the monitoring objects, which resulted in seven bridges being selected, including the Shirenzigou grand bridge, Kuntun viaduct, Wulunguhe grand bridge, Ermuchang grand bridge, Tarim river shaya bridge, Buerjin reservoir bridge, and Alaer trim river.

\section{(9) Tunnels}

The tunnels with a length of more than $1000 \mathrm{~m}$ were selected as monitoring objects, which resulted in eight tunnels being selected, including the Yuximolegai tunnel, Tielimaide tunnel, Sailimu lake tunnel, Jiangjungou tunnel, Gejiagou tunnel, right lane of Algert mountain tunnel, Kongur mountain tunnel, and East Tianshan mountain tunnel. 
Table 11. Importance of environmental monitoring objects in nature reserves.

\begin{tabular}{|c|c|c|c|c|c|c|c|c|c|}
\hline Monitoring Points & Name of Highway & $\begin{array}{l}\text { Highway } \\
\text { Rate }\end{array}$ & Traffic Flow & $\begin{array}{l}\text { Importance } \\
\text { of Highway }\end{array}$ & $\begin{array}{c}\text { Type of } \\
\text { Sensitive }\end{array}$ & $\begin{array}{l}\text { Protection } \\
\text { Level }\end{array}$ & $\begin{array}{l}\text { The Distance between the } \\
\text { Highway and Monitoring } \\
\text { Objects }\end{array}$ & $\begin{array}{c}\text { Importance } \\
\text { of Sensitive } \\
\text { Areas }\end{array}$ & $\begin{array}{l}\text { Importance of } \\
\text { Monitoring } \\
\text { Objects }\end{array}$ \\
\hline \multirow{2}{*}{$\begin{array}{l}\text { Huocheng four-legged tortoise } \\
\text { national nature reserve }\end{array}$} & \multirow{2}{*}{$\begin{array}{c}\text { G30 } \\
\text { Lianyungang-Khorgos }\end{array}$} & Expressway & 14,571 & \multirow{2}{*}{0.5325} & nature reserve & national & through & \multirow{2}{*}{0.4288} & \multirow{2}{*}{0.4633} \\
\hline & & 0.565 & 0.5 & & 0.3448 & 0.5556 & 0.4444 & & \\
\hline \multirow{2}{*}{$\begin{array}{l}\text { Bayanbulak national nature } \\
\text { reserve }\end{array}$} & \multirow[t]{2}{*}{ G217 Altay-Kuqa } & $\begin{array}{l}\text { National } \\
\text { highway }\end{array}$ & 3049 & \multirow[t]{2}{*}{0.2354} & nature reserve & national & through & \multirow[t]{2}{*}{0.4288} & \multirow[t]{2}{*}{0.3643} \\
\hline & & 0.304 & 0.1667 & & 0.3448 & 0.5556 & 0.4444 & & \\
\hline \multirow{2}{*}{$\begin{array}{l}\text { Lop Nor wild camel national } \\
\text { nature reserve }\end{array}$} & \multirow{2}{*}{$\begin{array}{c}\text { G315 } \\
\text { Xining-Kashi }\end{array}$} & $\begin{array}{l}\text { National } \\
\text { highway }\end{array}$ & 4948 & \multirow[t]{2}{*}{0.2354} & nature reserve & national & through & \multirow[t]{2}{*}{0.4288} & \multirow[t]{2}{*}{0.3643} \\
\hline & & 0.304 & 0.1667 & & 0.3448 & 0.5556 & 0.4444 & & \\
\hline \multirow{2}{*}{$\begin{array}{l}\text { Xinjiang Burgen beavers } \\
\text { national nature reserve }\end{array}$} & \multirow{2}{*}{$\begin{array}{c}\text { S320 } \\
\text { Takeshiken-Karatungk }\end{array}$} & $\begin{array}{l}\text { provincial } \\
\text { highway }\end{array}$ & 662 & \multirow[t]{2}{*}{0.1484} & nature reserve & national & through & \multirow[t]{2}{*}{0.4288} & \multirow[t]{2}{*}{0.3353} \\
\hline & & 0.13 & 0.1667 & & 0.3448 & 0.5556 & 0.4444 & & \\
\hline \multirow[t]{2}{*}{ Kanas national nature reserve } & \multirow{2}{*}{$\begin{array}{c}\text { S229 } \\
\text { Kanas-Heishantou }\end{array}$} & $\begin{array}{l}\text { provincial } \\
\text { highway }\end{array}$ & 2525 & \multirow[t]{2}{*}{0.1484} & nature reserve & national & through & \multirow[t]{2}{*}{0.4288} & \multirow[t]{2}{*}{0.3353} \\
\hline & & 0.13 & 0.1667 & & 0.3448 & 0.5556 & 0.4444 & & \\
\hline \multirow{2}{*}{$\begin{array}{l}\text { Xinjiang Tianchi Bogda peak } \\
\text { nature reserve }\end{array}$} & \multirow[t]{2}{*}{ S111 Urumqi-Tianchi } & $\begin{array}{l}\text { provincial } \\
\text { highway }\end{array}$ & 10,890 & \multirow[t]{2}{*}{0.315} & nature reserve & municipal & Adjacent less than $200 \mathrm{~m}$ & \multirow[t]{2}{*}{0.3393} & \multirow[t]{2}{*}{0.3312} \\
\hline & & 0.13 & 0.5 & & 0.3448 & 0.3333 & 0.3333 & & \\
\hline \multirow{2}{*}{$\begin{array}{l}\text { Kalamely ungulate wildlife } \\
\text { reserve }\end{array}$} & \multirow[t]{2}{*}{ G216 Altay_Balguntay } & $\begin{array}{r}\text { national } \\
\text { highway }\end{array}$ & 7655 & \multirow[t]{2}{*}{0.3187} & nature reserve & municipal & Adjacent more than $200 \mathrm{~m}$ & \multirow[t]{2}{*}{0.3238} & \multirow[t]{2}{*}{0.3221} \\
\hline & & 0.304 & 0.3333 & & 0.3448 & 0.3333 & 0.2222 & & \\
\hline Tashkurgan wildlife reserve & G219 Yecheng_Lhatse & $\begin{array}{r}\text { national } \\
\text { highway }\end{array}$ & 1644 & 0.2354 & nature reserve & municipal & through & 0.3548 & 0.3150 \\
\hline & & 0.304 & 0.1667 & & 0.3448 & 0.3333 & 0.4444 & & \\
\hline $\begin{array}{l}\text { Jintasi Mountain Meadow type } \\
\text { grassland nature reserve }\end{array}$ & $\begin{array}{l}\text { S230 Hongshanzui- } \\
\text { Altay }\end{array}$ & $\begin{array}{l}\text { provincial } \\
\text { highway }\end{array}$ & 1860 & 0.1484 & nature reserve & municipal & Adjacent less than $200 \mathrm{~m}$ & 0.3393 & 0.2757 \\
\hline & & 0.13 & 0.1667 & & 0.3448 & 0.3333 & 0.3333 & & \\
\hline
\end{tabular}


Table 12. Importance of environmental monitoring objects in scenic spots.

\begin{tabular}{|c|c|c|c|c|c|c|c|c|c|}
\hline Monitoring Points & Name of Highway & $\begin{array}{l}\text { Highway } \\
\text { Rate }\end{array}$ & Traffic Flow & $\begin{array}{l}\text { Importance } \\
\text { of Highway }\end{array}$ & $\begin{array}{c}\text { Type of } \\
\text { Sensitive }\end{array}$ & $\begin{array}{l}\text { Protection } \\
\text { Level }\end{array}$ & $\begin{array}{c}\text { The Distance between the } \\
\text { Highway and Monitoring } \\
\text { Objects }\end{array}$ & $\begin{array}{c}\text { Importance } \\
\text { of Sensitive } \\
\text { Areas }\end{array}$ & $\begin{array}{c}\text { Importance o } \\
\text { Monitoring } \\
\text { Objects }\end{array}$ \\
\hline \multirow{2}{*}{ Selimu lake scenic spot } & \multirow{2}{*}{$\begin{array}{c}\text { G30 } \\
\text { Lianyungang-Horgos }\end{array}$} & expressway & 14,571 & \multirow{2}{*}{0.5325} & scenic spot & national & Adjacent less than $200 \mathrm{~m}$ & \multirow{2}{*}{0.3405} & \multirow{2}{*}{0.4045} \\
\hline & & 0.565 & 0.5 & & 0.2069 & 0.5556 & 0.3333 & & \\
\hline \multirow[t]{2}{*}{ Tianshan Tianchi scenic spot } & \multirow[t]{2}{*}{ S111 Urumqi-Tianchi } & $\begin{array}{c}\text { Provincial } \\
\text { highway }\end{array}$ & 10,890 & \multirow[t]{2}{*}{0.315} & scenic spot & national & through & \multirow[t]{2}{*}{0.3560} & \multirow[t]{2}{*}{0.3423} \\
\hline & & 0.13 & 0.5 & & 0.2069 & 0.5556 & 0.4444 & & \\
\hline \multirow{2}{*}{$\begin{array}{l}\text { Grape valley in Turpan scenic } \\
\text { spot }\end{array}$} & \multirow{2}{*}{$\begin{array}{c}\text { G312 } \\
\text { Shanghai-Horgos }\end{array}$} & $\begin{array}{l}\text { National } \\
\text { highway }\end{array}$ & 9235 & \multirow[t]{2}{*}{0.3187} & scenic spot & municipal & Adjacent less than $200 \mathrm{~m}$ & \multirow[t]{2}{*}{0.2666} & \multirow[t]{2}{*}{0.2839} \\
\hline & & 0.304 & 0.3333 & & 0.2069 & 0.3333 & 0.3333 & & \\
\hline \multirow[t]{2}{*}{ Kanas scenic spot } & \multirow[t]{2}{*}{ S232 Kanas-Burqi } & $\begin{array}{l}\text { Provincial } \\
\text { highway }\end{array}$ & 4099 & \multirow[t]{2}{*}{0.1484} & scenic spot & municipal & through & \multirow[t]{2}{*}{0.2821} & \multirow[t]{2}{*}{0.2375} \\
\hline & & 0.13 & 0.1667 & & 0.2069 & 0.3333 & 0.4444 & & \\
\hline \multirow[t]{2}{*}{ Nalati grassland scenic spot } & \multirow{2}{*}{$\begin{array}{l}\text { G218Qingshui } \\
\text { river-Ruoqiang }\end{array}$} & $\begin{array}{l}\text { National } \\
\text { highway }\end{array}$ & 5418 & \multirow[t]{2}{*}{0.2354} & scenic spot & municipal & through & \multirow[t]{2}{*}{0.2821} & \multirow[t]{2}{*}{0.2665} \\
\hline & & 0.304 & 0.1667 & & 0.2069 & 0.3333 & 0.4444 & & \\
\hline \multirow{2}{*}{$\begin{array}{c}\text { Fuyun Keketuohai national } \\
\text { geopark }\end{array}$} & \multirow[t]{2}{*}{$\begin{array}{c}\text { S226 } \\
\text { Fuyun-Karatungk }\end{array}$} & $\begin{array}{c}\text { Provincial } \\
\text { highway }\end{array}$ & 5193 & \multirow[t]{2}{*}{0.2317} & scenic spot & scenic spot & through & \multirow[t]{2}{*}{0.2082} & \multirow[t]{2}{*}{0.2160} \\
\hline & & 0.13 & 0.3333 & & 0.2069 & 0.1111 & 0.4444 & & \\
\hline
\end{tabular}


Table 13. Importance of environmental monitoring objects in wetlands.

\begin{tabular}{|c|c|c|c|c|c|c|c|c|c|}
\hline Monitoring Points & Name of Highway & $\begin{array}{l}\text { Highway } \\
\text { Rate }\end{array}$ & Traffic Flow & $\begin{array}{l}\text { Importance } \\
\text { of Highway }\end{array}$ & $\begin{array}{c}\text { Type of } \\
\text { Sensitive }\end{array}$ & $\begin{array}{l}\text { Protection } \\
\text { Level }\end{array}$ & $\begin{array}{c}\text { The Distance between the } \\
\text { Highway and Monitoring } \\
\text { Objects }\end{array}$ & $\begin{array}{c}\text { Importance } \\
\text { of Sensitive } \\
\text { Areas } \\
\end{array}$ & $\begin{array}{c}\text { Importance o } \\
\text { Monitoring } \\
\text { Objects }\end{array}$ \\
\hline \multirow{2}{*}{ Urumqi river wetland } & \multirow{2}{*}{$\begin{array}{c}\text { G30 } \\
\text { Lianyungang-Khorgas }\end{array}$} & Expressway & 14,571 & \multirow{2}{*}{0.5325} & wetland & municipal & through & \multirow{2}{*}{0.3288} & \multirow{2}{*}{0.3967} \\
\hline & & 0.565 & 0.5 & & 0.1379 & 0.5833 & 0.4444 & & \\
\hline \multirow{2}{*}{ Xinjiang Uqilik wetland park } & \multirow{2}{*}{ G216 Altay-Barontai } & Expressway & 14,571 & \multirow{2}{*}{0.5325} & wetland & national & through & \multirow{2}{*}{0.2734} & \multirow{2}{*}{0.3597} \\
\hline & & 0.565 & 0.5 & & 0.1379 & 0.4167 & 0.4444 & & \\
\hline \multirow[t]{2}{*}{ Selimu lake wetland } & \multirow[t]{2}{*}{$\begin{array}{c}\text { G312 } \\
\text { Shanghai-Khorgas }\end{array}$} & $\begin{array}{l}\text { National } \\
\text { highway }\end{array}$ & 9235 & \multirow[t]{2}{*}{0.3187} & wetland & municipal & adjacent less than $200 \mathrm{~m}$ & \multirow[t]{2}{*}{0.3133} & \multirow[t]{2}{*}{0.3151} \\
\hline & & 0.304 & 0.3333 & & 0.1379 & 0.5833 & 0.3333 & & \\
\hline \multirow{2}{*}{$\begin{array}{c}\text { The lower Tarim river Yuli } \\
\text { wetland }\end{array}$} & \multirow{2}{*}{$\begin{array}{c}\text { G218 } \\
\text { Qingshuihe-Ruoqiang }\end{array}$} & $\begin{array}{l}\text { National } \\
\text { highway }\end{array}$ & 5418 & \multirow[t]{2}{*}{0.3187} & wetland & municipal & adjacent more than $200 \mathrm{~m}$ & \multirow[t]{2}{*}{0.2977} & \multirow[t]{2}{*}{0.3047} \\
\hline & & 0.304 & 0.3333 & & 0.1379 & 0.5833 & 0.2222 & & \\
\hline \multirow[t]{2}{*}{ Bosten lake wetland } & \multirow[t]{2}{*}{ S206 Shuiwen-Bohu } & $\begin{array}{l}\text { Provincial } \\
\text { highway }\end{array}$ & 8633 & \multirow[t]{2}{*}{0.2317} & wetland & municipal & through & \multirow[t]{2}{*}{0.3288} & \multirow[t]{2}{*}{0.2964} \\
\hline & & 0.13 & 0.3333 & & 0.1379 & 0.5833 & 0.4444 & & \\
\hline \multirow[t]{2}{*}{$\begin{array}{l}\text { Urumqi Chaiwopu lake national } \\
\text { wetland park }\end{array}$} & \multirow[t]{2}{*}{$\begin{array}{c}\text { G314 } \\
\text { Urumqi-Khunjerab }\end{array}$} & $\begin{array}{l}\text { National } \\
\text { highway }\end{array}$ & 5215 & \multirow[t]{2}{*}{0.3187} & wetland & national & adjacent less than $200 \mathrm{~m}$ & \multirow[t]{2}{*}{0.2579} & \multirow[t]{2}{*}{0.2781} \\
\hline & & 0.304 & 0.3333 & & 0.1379 & 0.4167 & 0.3333 & & \\
\hline \multirow[t]{2}{*}{ Ebinur lake wetland } & \multirow[t]{2}{*}{ S305 Heshuo-Hejing } & $\begin{array}{l}\text { Provincial } \\
\text { highway }\end{array}$ & 3524 & \multirow[t]{2}{*}{0.1484} & wetland & municipal & adjacent less than $200 \mathrm{~m}$ & \multirow[t]{2}{*}{0.3133} & \multirow[t]{2}{*}{0.2583} \\
\hline & & 0.13 & 0.1667 & & 0.1379 & 0.5833 & 0.3333 & & \\
\hline \multirow[t]{2}{*}{$\begin{array}{c}\text { Fuyun Keketuohai national } \\
\text { wetland park }\end{array}$} & $\begin{array}{c}\text { S229 } \\
\text { Kanas-Heishantou }\end{array}$ & $\begin{array}{l}\text { Provincial } \\
\text { highway }\end{array}$ & 2525 & 0.1484 & wetland & national & adjacent more than $200 \mathrm{~m}$ & 0.2424 & 0.2110 \\
\hline & & 0.13 & 0.1667 & & 0.1379 & 0.4167 & 0.2222 & & \\
\hline
\end{tabular}


Table 14. Importance of environmental monitoring objects in rivers.

\begin{tabular}{|c|c|c|c|c|c|c|c|c|c|}
\hline Names & Name of Highway & Highway Rate & Traffic Flow & $\begin{array}{l}\text { Importance } \\
\text { of Highway }\end{array}$ & $\begin{array}{l}\text { Type of } \\
\text { Sensitive }\end{array}$ & $\begin{array}{c}\text { Protection } \\
\text { Level }\end{array}$ & $\begin{array}{c}\text { The Distance between the } \\
\text { Highway and Monitoring } \\
\text { Objects }\end{array}$ & $\begin{array}{c}\text { Importance of } \\
\text { Sensitive Areas }\end{array}$ & $\begin{array}{c}\text { Importance of } \\
\text { Monitoring Objects }\end{array}$ \\
\hline \multirow{2}{*}{ Yarkant River } & \multirow{2}{*}{ G315 Xining_Kashgar } & Expressway & 10,916 & \multirow{2}{*}{0.5325} & river & main river & through & \multirow{2}{*}{0.3949} & \multirow{2}{*}{0.4407} \\
\hline & & 0.565 & 0.5 & & 0.1724 & 0.7273 & 0.4444 & & \\
\hline \multirow{2}{*}{ Urumqi river } & \multirow{2}{*}{ G216 Altay-Barontai } & National highway & 7655 & \multirow{2}{*}{0.3187} & river & main river & through & \multirow{2}{*}{0.3949} & \multirow{2}{*}{0.3695} \\
\hline & & 0.304 & 0.3333 & & 0.1724 & 0.7273 & 0.4444 & & \\
\hline \multirow{2}{*}{ Eerqisi River } & \multirow{2}{*}{ G216 Altay-Barontai } & National highway & 7655 & \multirow{2}{*}{0.3187} & river & main river & through & \multirow{2}{*}{0.3949} & \multirow{2}{*}{0.3695} \\
\hline & & 0.304 & 0.3333 & & 0.1724 & 0.7273 & 0.4444 & & \\
\hline \multirow{2}{*}{ Aksu River } & \multirow{2}{*}{ G314 Urumqi-Khunjerab } & National highway & 5215 & \multirow{2}{*}{0.3187} & river & main river & through & \multirow{2}{*}{0.3949} & \multirow{2}{*}{0.3695} \\
\hline & & 0.304 & 0.3333 & & 0.1724 & 0.7273 & 0.4444 & & \\
\hline \multirow{2}{*}{ Konqi River } & \multirow{2}{*}{ G314 Urumqi-Khunjerab } & National highway & 5215 & \multirow{2}{*}{0.3187} & river & main river & through & \multirow{2}{*}{0.3949} & \multirow{2}{*}{0.3695} \\
\hline & & 0.304 & 0.3333 & & 0.1724 & 0.7273 & 0.4444 & & \\
\hline \multirow[t]{2}{*}{ Ulungur River } & \multirow[t]{2}{*}{ G216 Altay-Barontai } & National highway & 7655 & \multirow{2}{*}{0.3187} & river & main river & through & \multirow{2}{*}{0.3949} & 0.3695 \\
\hline & & 0.304 & 0.3333 & & 0.1724 & 0.7273 & 0.4444 & & \\
\hline Tarim River & G217 Altay-Kuga & National highway & 3049 & 0.2354 & river & main river & through & 0.3949 & 0.3417 \\
\hline & & 0.304 & 0.1667 & & 0.1724 & 0.7273 & 0.4444 & & \\
\hline Hutubi River & G30 Ljanyungan $\alpha$-Khorgas & Expressway & 14,571 & 05325 & river & else & through & 02436 & 03399 \\
\hline nutuor hiver & 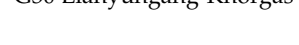 & 0.565 & 0.5 & 0.5020 & 0.1724 & 0.2723 & 0.4444 & 0.2450 & 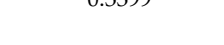 \\
\hline Hotan River & G217 Altay-Kuqa & National highway & 3049 & 0.2354 & river & main river & adjacent less than $200 \mathrm{~m}$ & 0.3793 & 0.3314 \\
\hline & & 0.304 & 0.1667 & & 0.1724 & 0.7273 & 0.3333 & & \\
\hline Kalakuri Lake & G314 Urumgi-Khunjerab & National highway & 5215 & 0.3187 & river & else & through & 0.2436 & 0.2686 \\
\hline & & 0.304 & 0.3333 & & 0.1724 & 0.2723 & 0.4444 & & \\
\hline Poplar River & G314 Urumgi-Khunjerab & National highway & 5215 & 0.3187 & river & else & through & 0.2436 & 0.2686 \\
\hline & & 0.304 & 0.3333 & & 0.1724 & 0.2723 & 0.4444 & & \\
\hline Weigan River & G314 Urumgi-Khunjerab & National highway & 5215 & 0.3187 & river & else & through & 0.2436 & 0.2686 \\
\hline & & 0.304 & 0.3333 & & 0.1724 & 0.2723 & 0.4444 & & \\
\hline Niya River & G315 Xining-Kashgar & National highway & 4989 & 0.2354 & river & else & through & 0.2436 & 0.2408 \\
\hline & & 0.304 & 0.1667 & & 0.1724 & 0.2723 & 0.4444 & & \\
\hline Oargan River & G315 Xining-Kashgar & National highway & 4989 & 0.2354 & river & else & through & 0.2436 & 0.2408 \\
\hline & & 0.304 & 0.1667 & & 0.1724 & 0.2723 & 0.4444 & & \\
\hline Keriva River & G315 Xining-Kashoar & National highway & 4989 & 02354 & river & else & through & 02436 & 02408 \\
\hline & & 0.304 & 0.1667 & & 0.1724 & 0.2723 & 0.4444 & & \\
\hline
\end{tabular}


Table 14. Cont.

\begin{tabular}{|c|c|c|c|c|c|c|c|c|c|}
\hline Names & Name of Highway & Highway Rate & Traffic Flow & $\begin{array}{l}\text { Importance } \\
\text { of Highway }\end{array}$ & $\begin{array}{c}\text { Type of } \\
\text { Sensitive }\end{array}$ & $\begin{array}{l}\text { Protection } \\
\text { Level }\end{array}$ & $\begin{array}{l}\text { The Distance between the } \\
\text { Highway and Monitoring } \\
\text { Objects }\end{array}$ & $\begin{array}{l}\text { Importance of } \\
\text { Sensitive Areas }\end{array}$ & $\begin{array}{c}\text { Importance of } \\
\text { Monitoring Objects }\end{array}$ \\
\hline \multirow{2}{*}{ Yurungkash River } & \multirow{2}{*}{ G315 Xining-Kashgar } & National highway & 4989 & \multirow{2}{*}{0.2354} & river & else & through & \multirow{2}{*}{0.2436} & \multirow{2}{*}{0.2408} \\
\hline & & 0.304 & 0.1667 & & 0.1724 & 0.2723 & 0.4444 & & \\
\hline \multirow{2}{*}{ Karrakesh River } & \multirow{2}{*}{ G315 Xining-Kashgar } & National highway & 4989 & \multirow{2}{*}{0.2354} & river & else & through & \multirow{2}{*}{0.2436} & \multirow{2}{*}{0.2408} \\
\hline & & 0.304 & 0.1667 & & 0.1724 & 0.2723 & 0.4444 & & \\
\hline \multirow{2}{*}{ Kuitun River } & \multirow{2}{*}{ G217 Altay-Kuqa } & National highway & 3049 & \multirow{2}{*}{0.2354} & river & else & through & \multirow{2}{*}{0.2436} & \multirow{2}{*}{0.2408} \\
\hline & & 0.304 & 0.1667 & & 0.1724 & 0.2723 & 0.4444 & & \\
\hline \multirow{2}{*}{ Kaidu River } & \multirow{2}{*}{ G217 Altay-Kuqa } & National highway & 3049 & \multirow{2}{*}{0.2354} & river & else & through & \multirow{2}{*}{0.2436} & \multirow{2}{*}{0.2408} \\
\hline & & 0.304 & 0.1667 & & 0.1724 & 0.2723 & 0.4444 & & \\
\hline \multirow{2}{*}{ Darjegran river } & \multirow{2}{*}{ G217 Altay-Kuqa } & National highway & 3049 & \multirow{2}{*}{0.2354} & river & else & through & \multirow{2}{*}{0.2436} & \multirow{2}{*}{0.2408} \\
\hline & & 0.304 & 0.1667 & & 0.1724 & 0.2723 & 0.4444 & & \\
\hline \multirow{2}{*}{ Kashi River } & \multirow{2}{*}{ G217 Altay-Kuqa } & National highway & 3049 & \multirow{2}{*}{0.2354} & river & else & through & 0.2436 & 0.2408 \\
\hline & & 0.304 & 0.1667 & & 0.1724 & 0.2723 & 0.4444 & & \\
\hline Kunes River & G217 Altay-Kuqa & National highway & 3049 & 0.2354 & river & else & through & 0.2436 & 0.2408 \\
\hline & & 0.304 & 0.1667 & & 0.1724 & 0.2723 & 0.4444 & & \\
\hline Indalia River & G217 Altay-Kuqa & National highway & 3049 & 0.2354 & river & else & through & 0.2436 & 0.2408 \\
\hline & & 0.304 & 0.1667 & & 0.1724 & 0.2723 & 0.4444 & & \\
\hline Toutun Reservoir & S104 Urumqi-Liuhuanggou & Provincial highway & 5418 & 0.2317 & river & else & through & 0.2436 & 0.2396 \\
\hline & & 0.13 & 0.3333 & & 0.1724 & 0.2723 & 0.4444 & & \\
\hline Tekes river & S316 Fengchang-Hantian & Provincial highway & 7598 & 0.2317 & river & else & through & 0.2436 & 0.2396 \\
\hline & & 0.13 & 0.3333 & & 0.1724 & 0.2723 & 0.4444 & 0.2750 & 0.2000 \\
\hline Kashigar River & S215 Sanchakou-Shache & Provincial way & 6882 & 0.2317 & river & else & through & 0.2436 & 0.2396 \\
\hline & & 0.13 & 0.3333 & & 0.1724 & 0.2723 & 0.4444 & & \\
\hline Chonghuer River & S232 Kanas-Burgin & Provincial highway & 4099 & 0.1484 & river & else & through & 0.2436 & 0.2118 \\
\hline & & 0.13 & 0.1667 & & 0.1724 & 0.2723 & 0.4444 & & \\
\hline Zhaosu River & S237 Yining-Muzart & Provincial highway & 3856 & 0.1484 & river & else & through & 0.2436 & 0.2118 \\
\hline 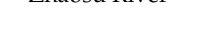 & & 0.13 & 0.1667 & 0.101 & 0.1724 & 0.2723 & 0.4444 & & \\
\hline Shichengzi River & S303 Hami-Fukang & Provincial highway & 3743 & 0.1484 & river & else & through & 0.2436 & 02118 \\
\hline & & 0.13 & 0.1667 & & 0.1724 & 0.2723 & 0.4444 & & \\
\hline Tuoshigan River & S306 Aksu-Bapanshuimo & Provincial highway & 3977 & 01484 & river & else & through & 02436 & 02118 \\
\hline & & 0.13 & 0.1667 & & 0.1724 & 0.2723 & 0.4444 & & \\
\hline Kizilsu River & S309 Atush-Irkshtan & Provincial highway & 1818 & 0.1484 & river & else & through & 0.2436 & 0.2118 \\
\hline & & 0.13 & 0.1667 & & 0.1724 & 0.2723 & 0.4444 & & \\
\hline
\end{tabular}


Table 15. Importance of environmental monitoring objects in reservoirs.

\begin{tabular}{|c|c|c|c|c|c|c|c|c|c|}
\hline Monitoring Points & Name of Highway & Highway Rate & Traffic Flow & $\begin{array}{l}\text { Importance } \\
\text { of Highway }\end{array}$ & $\begin{array}{l}\text { Type of } \\
\text { Sensitive }\end{array}$ & $\begin{array}{l}\text { Protection } \\
\text { Level }\end{array}$ & $\begin{array}{c}\text { The Distance between the } \\
\text { Highway and Monitoring } \\
\text { Objects }\end{array}$ & $\begin{array}{l}\text { Importance of } \\
\text { Sensitive Areas }\end{array}$ & $\begin{array}{c}\text { Importance of } \\
\text { Monitoring Objects }\end{array}$ \\
\hline \multirow[t]{2}{*}{ Tokayi reservoir } & \multirow[t]{2}{*}{ G314 Urumqi-Khunjerab } & National highway & 5215 & \multirow[t]{2}{*}{0.3187} & reservoir & $\begin{array}{l}\text { main } \\
\text { reservoir }\end{array}$ & through & \multirow[t]{2}{*}{0.3766} & \multirow[t]{2}{*}{0.3573} \\
\hline & & 0.304 & 0.3333 & & 0.1379 & 0.7273 & 0.4444 & & \\
\hline \multirow[t]{2}{*}{ Chara reservoir } & \multirow[t]{2}{*}{ G218 Qingshuihe-Ruoqiang } & National highway & 5418 & \multirow[t]{2}{*}{0.3187} & reservoir & $\begin{array}{l}\text { main } \\
\text { reservoir }\end{array}$ & adjacent less than $200 \mathrm{~m}$ & \multirow[t]{2}{*}{0.3611} & \multirow[t]{2}{*}{0.347} \\
\hline & & 0.304 & 0.3333 & & 0.1379 & 0.7273 & 0.3333 & & \\
\hline \multirow[t]{2}{*}{ Aweitan reservoir } & \multirow[t]{2}{*}{ G216 Altay-Barontai } & National highway & 7655 & \multirow[t]{2}{*}{0.3187} & reservoir & $\begin{array}{l}\text { important } \\
\text { reservoir }\end{array}$ & adjacent less than $200 \mathrm{~m}$ & \multirow[t]{2}{*}{0.3611} & \multirow[t]{2}{*}{0.347} \\
\hline & & 0.304 & 0.3333 & & 0.1379 & 0.7273 & 0.3333 & & \\
\hline \multirow[t]{2}{*}{ Muguhu reservoir } & \multirow[t]{2}{*}{ S204 Mossel Bay_Shihezi } & National highway & 10,635 & \multirow[t]{2}{*}{0.315} & reservoir & $\begin{array}{c}\text { main } \\
\text { reservoir }\end{array}$ & adjacent less than $200 \mathrm{~m}$ & \multirow[t]{2}{*}{0.3611} & \multirow[t]{2}{*}{0.3458} \\
\hline & & 0.13 & 0.5 & & 0.1379 & 0.7273 & 0.3333 & & \\
\hline \multirow[t]{2}{*}{ Jiahezi reservoir } & \multirow[t]{2}{*}{ S201 EMin-Yushugou } & Provincial highway & 6829 & \multirow[t]{2}{*}{0.2317} & reservoir & $\begin{array}{l}\text { main } \\
\text { reservoir }\end{array}$ & through & \multirow[t]{2}{*}{0.3766} & \multirow[t]{2}{*}{0.3283} \\
\hline & & 0.13 & 0.3333 & & 0.1379 & 0.7273 & 0.4444 & & \\
\hline \multirow[t]{2}{*}{ Duolang reservoir } & \multirow[t]{2}{*}{ S207 Aksu-Aral } & Provincial highway & 5231 & \multirow[t]{2}{*}{0.2317} & reservoir & $\begin{array}{l}\text { main } \\
\text { reservoir }\end{array}$ & through & \multirow[t]{2}{*}{0.3766} & \multirow[t]{2}{*}{0.3283} \\
\hline & & 0.13 & 0.3333 & & 0.1379 & 0.7273 & 0.4444 & & \\
\hline \multirow{2}{*}{ Kalabash reservoir } & \multirow{2}{*}{ G3012Turpan-Hetian } & Expressway & 10,916 & 0.5325 & reservoir & else & adjacent less than $200 \mathrm{~m}$ & 0.2099 & 0.3174 \\
\hline & & 0.565 & 0.5 & & 0.1379 & 0.2723 & 0.3333 & & \\
\hline Daxihaizi reservoir & G218 Qingshuihe-Ruoqiang & National highway & 5418 & 0.3187 & reservoir & else & adjacent less than $200 \mathrm{~m}$ & 0.1943 & 0.2358 \\
\hline & & 0.304 & 0.3333 & & 0.1379 & 0.2723 & 0.2222 & . & . \\
\hline Kala reservoir & G218 Qingshuihe-Ruoqiang & National highway & 5418 & 0.3187 & reservoir & else & through & 0.2254 & 0.2565 \\
\hline & & 0.304 & 0.3333 & & 0.1379 & 0.2723 & 0.4444 & & \\
\hline Youth reservoir & G314 Urumgi-Khunierab & National highway & 5215 & 03187 & reservoir & else & through & 02254 & 02565 \\
\hline & & 0.304 & 0.3333 & & 0.1379 & 0.2723 & 0.4444 & & \\
\hline Secor reservoir & G314 Urumqi-Khunjerab & National highway & 5215 & 0.3187 & reservoir & else & adjacent less than $200 \mathrm{~m}$ & 0.2099 & 0.2461 \\
\hline & & 0.304 & 0.3333 & & 0.1379 & 0.2723 & 0.3333 & & \\
\hline Dongfanghong reservoir & G315 Xining_Kashgar & National highway & 4948 & 0.2354 & reservoir & else & adjacent less than $200 \mathrm{~m}$ & 0.2099 & 0.2184 \\
\hline & & 0.304 & 0.1667 & & 0.1379 & 0.2723 & 0.3333 & & \\
\hline
\end{tabular}


Table 15. Cont.

\begin{tabular}{|c|c|c|c|c|c|c|c|c|c|}
\hline Monitoring Points & Name of Highway & Highway Rate & Traffic Flow & $\begin{array}{l}\text { Importance } \\
\text { of Highway }\end{array}$ & $\begin{array}{l}\text { Type of } \\
\text { Sensitive }\end{array}$ & $\begin{array}{l}\text { Protection } \\
\text { Level }\end{array}$ & $\begin{array}{l}\text { The Distance between the } \\
\text { Highway and Monitoring } \\
\text { Objects }\end{array}$ & $\begin{array}{l}\text { Importance of } \\
\text { Sensitive Areas }\end{array}$ & $\begin{array}{c}\text { Importance of } \\
\text { Monitoring Objects }\end{array}$ \\
\hline \multirow{2}{*}{ Baishitan reservoir } & \multirow{2}{*}{ G217 Altay—Kuqa } & National highway & 3049 & \multirow{2}{*}{0.2354} & reservoir & else & adjacent less than $200 \mathrm{~m}$ & \multirow{2}{*}{0.2099} & \multirow{2}{*}{0.2184} \\
\hline & & 0.304 & 0.1667 & & 0.1379 & 0.2723 & 0.3333 & & \\
\hline \multirow{2}{*}{ Hankool reservoir } & \multirow{2}{*}{ S234 Maigaiti-Yecheng } & Provincial highway & 5219 & \multirow{2}{*}{0.2317} & reservoir & else & adjacent less than $200 \mathrm{~m}$ & \multirow{2}{*}{0.2099} & \multirow{2}{*}{0.2171} \\
\hline & & 0.13 & 0.3333 & & 0.1379 & 0.2723 & 0.3333 & & \\
\hline \multirow{2}{*}{ Jieranlik reservoir } & \multirow[t]{2}{*}{ G217 Altay-Kuqa } & National highway & 3049 & \multirow{2}{*}{0.2354} & reservoir & else & adjacent more than $200 \mathrm{~m}$ & \multirow{2}{*}{0.1943} & \multirow{2}{*}{0.208} \\
\hline & & 0.304 & 0.1667 & & 0.1379 & 0.2723 & 0.2222 & & \\
\hline \multirow{2}{*}{ Yonganba reservoir } & \multirow{2}{*}{ S218 Kuytun—Dushanzi } & Provincial highway & 6852 & \multirow{2}{*}{0.2317} & reservoir & else & adjacent more than $200 \mathrm{~m}$ & \multirow{2}{*}{0.1943} & \multirow{2}{*}{0.2068} \\
\hline & & 0.13 & 0.3333 & & 0.1379 & 0.2723 & 0.2222 & & \\
\hline \multirow{2}{*}{ Burqin reservoir bridge } & \multirow{2}{*}{ S232 Kanas-Burqin } & Provincial highway & 4099 & \multirow{2}{*}{0.1484} & reservoir & else & adjacent more than $200 \mathrm{~m}$ & \multirow{2}{*}{0.1943} & \multirow{2}{*}{0.179} \\
\hline & & 0.13 & 0.1667 & & 0.1379 & 0.2723 & 0.2222 & & \\
\hline
\end{tabular}


4.3.4. Layout Planning of Mobile Environment Monitoring Points in the Near Future (13th Five-Year Plan)

According to the above studies, there are two environmental monitoring sub-stations and online monitoring points in the most recent plan (the 13th five-year plan), as well as a total of 73 mobile environment monitoring points, and their distribution is shown in Figure 1.

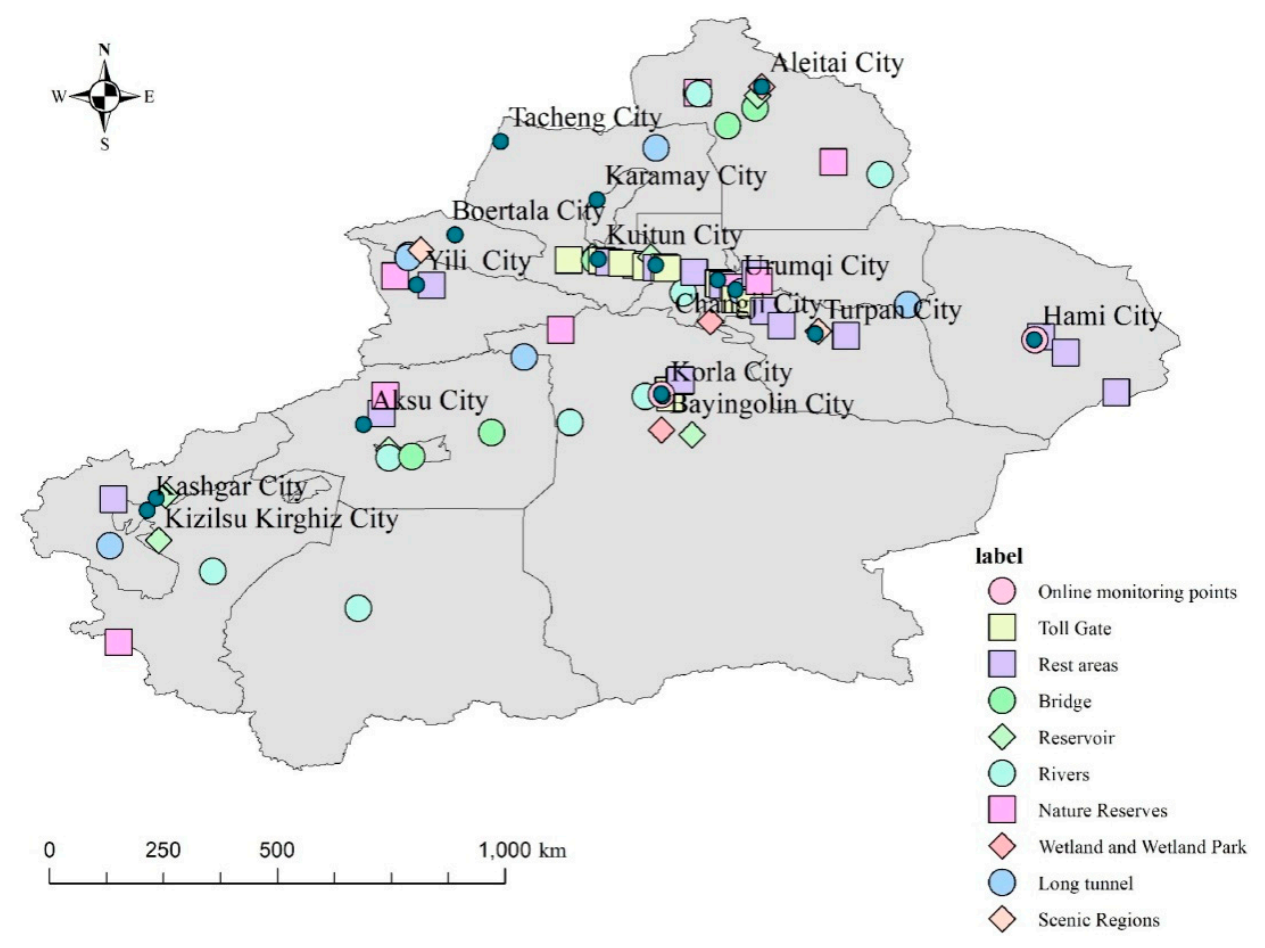

Figure 1. Layout planning of mobile environment monitoring points in the near future.

4.3.5. Long-Term (the 14th and the 15th Five-Year Plan) Layout Planning of Mobile Environment Monitoring Points

According to the Provincial Road Planning of the Xinjiang Uygur Autonomous Region (2016-2030) and the Environmental Impact Assessment Opinions of the Provincial Road Planning of the Xinjiang Uygur Autonomous Region (2016-2030), 35 monitoring points of the long-term mobile environment were determined by analyzing the ecological environmentally sensitive areas that may be involved in the highways during the 13th to the 15th five-year period.

\section{(1) Nature reserves}

Four environmental monitoring stations through or adjacent to the nature reserves were selected as the monitoring objects, including the Burgen beaver protect region, Xinjiang Kalamailishan ungulates nature reserve, Xinjiang Kunse Tianshan meadow grassland nature reserve, and Tashikuergan nature reserve.

\section{(2) Wetland parks}

Twelve environmental monitoring stations through or adjacent to the wetland parks were taken as monitoring objects, including the Pamirs plateau wetland nature reserve, Shaya county upstream of the Tarim river wetland nature reserve, Yingjisha national wetland park, Zepyerqiang river national wetland park, Yili Yamatu national wetland park, Uzilike national wetland park, Manas national wetland park, Chabchhar river national wetland park, Jimusaer Beiting national wetland park, Hoboksar national wetland park, Turks national wetland park, and Ushtogan river national wetland park. 
(3) Forest parks

Three environmental monitoring points through or adjacent to forest parks were selected as the monitoring objects, including the Tianshan grand canyon national forest park, Nalati national forest park, and Gongnais national forest park.

\section{(4) Scenic spots}

Fifteen environmental monitoring stations through or adjacent to the scenic spots were selected as monitoring objects, including the Sayram lake scenic spot, Kanas scenic spot, Wucai beach scenic spot, Grape valley 5A scenic spot, Kalajun scenic spot, Birch forest in Habahe county, Wenquan holy spring scenic area, Guyang wetland area, Tang Blah scenic spot, wild walnut scenic spot, Poplar forest scenic spot, Bosten lake scenic spot, Awat Daolang tribal area, cocoa haifeng scenic area, and Bayanbulak scenic spot.

\section{(5) Water sources}

The Wulapo water source was selected as the monitoring object of the Xinjiang highway transportation environment monitoring network.

There were two environmental monitoring sub-stations and online monitoring points in the long-term planning and 35 mobile environmental monitoring points, and their distribution is shown in Figure 2.

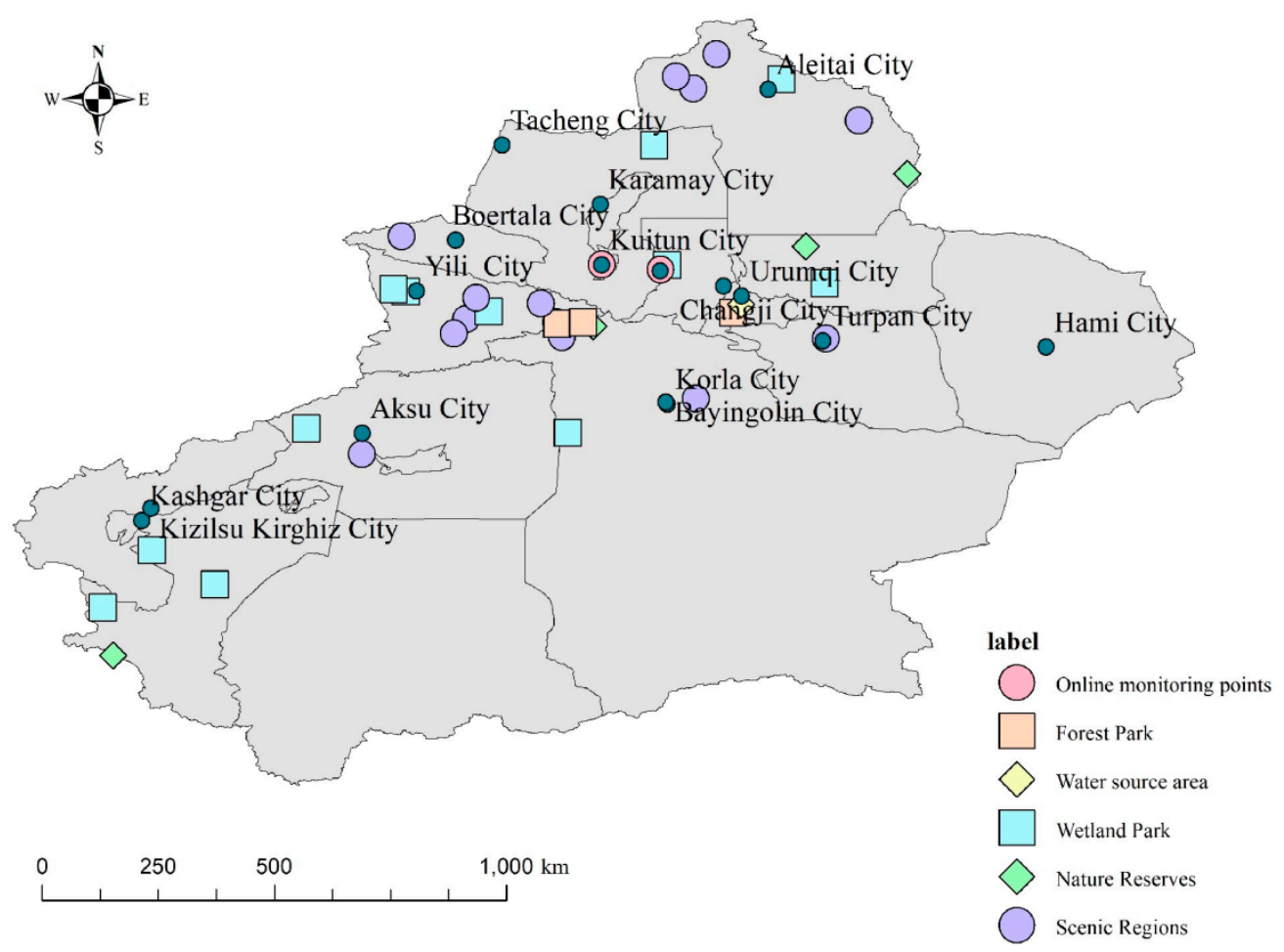

Figure 2. Long-term (the 14th and the 15th five-year plan) layout planning of mobile environment monitoring points.

\section{Conclusions}

This paper set environmental monitoring stations in highway environmentally sensitive areas and other important areas of Xinjiang based on data collection, the analytic hierarchy process (AHP), and important degree method, and constructed short-term and long-term trinity traffic environmental monitoring network systems covering traffic environment monitoring substations, online traffic 
environmental monitoring stations, and mobile traffic environmental monitoring stations in accordance with such indicators as the traffic hub, highway grade, traffic flow, and environmental sensitivity. Based on the above research, there are two traffic environment monitoring substations, two online traffic environmental monitoring stations, and 73 mobile traffic environmental monitoring stations in short-term planning, while there are two traffic environment monitoring substations, two online traffic environmental monitoring stations, and 35 mobile traffic environmental monitoring stations in short-term planning. The monitoring sub-stations, online monitoring stations, and mobile monitoring stations together constitute the basic framework of the road traffic environment monitoring layout network, which can realize comprehensive monitoring at a limited cost and provide a basis for continuous and stable acquisition of road traffic environment monitoring data.

Author Contributions: Conceptualization, N.Z. and T.L.; methodology, N.Z. and M.L.; Data curation, N.Z. and C.W.; resources, C.W. and Y.W.; writing-original draft preparation, N.Z.; writing-review and editing, T.L. and M.L.; formal analysis, X.Z.; visualization, N.Z.; supervision, T.L. and M.L.; project administration, X.Z.; funding acquisition, T.L. All authors have read and agreed to the published version of the manuscript.

Funding: The relevant researches done in this paper are supported by the Natural Science Foundation of China (Grant No. 41801119), Royal Society and NSFC International Exchanges project (IEC \NSFC \170391). Social Science Foundation of China (Grant No. 18FGL003), Key Project of National Language Commission (ZDI135-67), China Postdoctoral Science Foundation funded project (Grant No. 2018M631220), Excellent Youth Foundation of Xinjiang Scientific Committee (Grant No. 2017Q071), and Foundation of Shihezi University (RCSX201754).

Conflicts of Interest: The authors declare no conflict of interest. The funders had no role in the design of the study; in the collection, analyses or interpretation of data; in the writing of the manuscript or in the decision to publish the results.

\section{References}

1. Chen, P. Visualization of real-time monitoring datagraphic of urban environmental quality. EURASIP J. Image Video Process. 2019, 2019, 42. [CrossRef]

2. Ștefănut, S.; Öllerer, K.; Manole, A. National environmental quality assessment and monitoring of atmospheric heavy metal pollution-A moss bag approach. J. Environ. Manag. 2019, 248, 109224. [CrossRef] [PubMed]

3. Foster, K.R.; Davidson, C.; Tanna, R.N.; Spink, D. Introduction to the virtual special issue monitoring ecological responses to air quality and atmospheric deposition in the Athabasca Oil Sands region the wood Buffalo environmental Association's Forest health monitoring program. Sci. Total Environ. 2019, 686, 345-359. [CrossRef] [PubMed]

4. Kazemi-Beydokhti, M.; Abbaspour, R.A.; Kheradmandi, M.; Bozorgi-Amiri, A. Determination of the physical domain for air quality monitoring stations using the ANP-OWA method in GIS. Environ. Monit. Assess. 2019, 191, 299. [CrossRef] [PubMed]

5. Li, J.; Zhang, H.; Luo, Y.; Deng, X.; Grieneisen, M.L.; Yang, F. Stepwise genetic algorithm for adaptive management: Application to air quality monitoring network optimization. Atmos. Environ. 2019, 215, 116894. [CrossRef]

6. Abdul-Wahab, S.A.; Charabi, Y.; Osman, S.; Yetilmezsoy, K.; Osman, I.I. Prediction of optimum sampling rates of air quality monitoring stations using hierarchical fuzzy logic control system. Atmos. Pollut. Res. 2019, 10, 1931-1943. [CrossRef]

7. Ma, M.; Chen, Y.; Ding, F.; Pu, Z.; Liang, X. The representativeness of air quality monitoring sites in the urban areas of a mountainous city. J. Meteorol. Res. 2019, 33, 236-250. [CrossRef]

8. Dogruparmak, S.C.; Keskin, G.A.; Yaman, S.; Alkan, A. Using principal component analysis and fuzzy c-means clustering for the assessment of air quality monitoring. Atmos. Pollut. Res. 2014, 5, 656-663. [CrossRef]

9. Wei, P.; Ning, Z.; Westerdahl, D.; Lam, Y.F.; Louie, P.K.; Sharpe, R. Solar-powered air quality monitor applied under subtropical conditions in Hong Kong: Performance evaluation and application for pollution source tracking. Atmos. Environ. 2019, 214, 116825. [CrossRef]

10. Kaduwela, A.P.; Jrade, E.; Brusseau, M.; Morris, S.; Morris, J.; Risk, V. Development of a Low-Cost Air Sensor package and Indoor Air Quality Monitoring in a California Middle School: Detection of a Distant Wildfire. J. Air Waste Manag. Assoc. 2019, 69, 1015-1022. [CrossRef] 
11. Perrino, C.; Ramirez, D.; Allegrini, I. Monitoring acidic air pollutants near Rome by means of diffusion lines: Development of a specific quality control procedure. Atmos. Environ. 2001, 35, 331-341. [CrossRef]

12. Abdulsalam, H.M.; Ali, B.A.; AlYatama, A.; AlRoumi, E.S. Deploying a LEACH data aggregation technique for air quality monitoring in wireless sensor network. Procedia Comput. Sci. 2014, 34, 499-504. [CrossRef]

13. Bender, F.; Barié, N.; Romoudis, G.; Voigt, A.; Rapp, M. Development of a preconcentration unit for a SAW sensor micro array and its use for indoor air quality monitoring. Sens. Actuators B Chem. 2003, 93, 135-141. [CrossRef]

14. Nicoletti, S.; Dori, L.; Cardinali, G.C.; Parisini, A. Gas sensors for air quality monitoring: Realisation and characterisation of undoped and noble metal-doped $\mathrm{SnO}_{2}$ thin sensing films deposited by the pulsed laser ablation. Sens. Actuators B Chem. 1999, 60, 90-96. [CrossRef]

15. Qian, J.; Zhou, Y.H.; Ai, J.Y. Application of genetic neural network in layout optimization of water quality monitoring points. Environ. Eng. 2019, 37, 177-183.

16. Chen, L.; Liu, T.; Cui, H.S.; Wu, C.L. Exploration of Highway Soil and Water Conservation Monitoring Layout Based on ArcGIS and Cluster Analysis: A Case Study of Sai-Bai Expressway. Transp. Res. 2017, 3, 22-29.

17. Gao, X.P.; Zi, T.L.; Sun, B.W. On the optimized monitoring project layout for the river water quality based on the analytic hierarchy process. J. Saf. Environ. 2017, 17, 1190-1194.

18. Li, M.; Xiong, L.L. Application of nearness degree method in optimal layout of Poyang lake water resources dynamic monitoring station. Water Resour. Res. 2014, 3, 444-451. [CrossRef]

19. Wei, G.X. Study on Optimization Method of Distributed Water Quality Monitoring and Early Warning Network Monitoring Point Layout. Ph.D. Thesis, Zhejiang University, Zhejiang, China, 2015.

20. Hu, X.L. Study on Huaihe River Basin Soil and Water Conservation Monitoring Zoning and Stations Layout. Ph.D. Thesis, Shandong Agricultural University, Shandong, China, 2013.

21. Haver, S.M.; Gedamke, J.; Hatch, L.T.; Dziak, R.P.; Van Parijs, S.; McKenna, M.F. Monitoring long-term soundscape trends in US waters: The NOAA/NPS ocean noise reference station network. Mar. Policy 2018, 90, 6-13. [CrossRef]

22. Schaeffer, B.A.; Bailey, S.W.; Conmy, R.N.; Galvin, M.; Ignatius, A.R.; Johnston, J.M. Mobile device application for monitoring cyanobacteria harmful algal blooms using Sentinel-3 satellite Ocean and Land Colour Instruments. Environ. Modell. Softw. 2018, 109, 93-103. [CrossRef]

23. Nyman, E. Techno-optimism and ocean governance: New trends in maritime monitoring. Mar. Policy 2019, 99, 30-33. [CrossRef]

24. Carlson, D.F.; Fürsterling, A.; Vesterled, L.; Skovby, M.; Pedersen, S.S.; Melvad, C.; Rysgaard, S. An affordable and portable autonomous surface vehicle with obstacle avoidance for coastal ocean monitoring. Hardwarex 2019, 5, e00059. [CrossRef]

25. Wang, S.; Liu, L.; Qu, L.; Yu, C.; Sun, Y.; Gao, F.; Dong, J. Accurate Ulva prolifera regions extraction of UAV images with superpixel and CNNs for ocean environment monitoring. Neurocomputing 2019, 348, 158-168. [CrossRef]

26. Fernández-Gavela, A.; Herranz, S.; Chocarro, B.; Falke, F.; Schreuder, E.; Leeuwis, H. Full integration of photonic nanoimmunosensors in portable platforms for on-line monitoring of ocean pollutants. Sens. Actuators B Chem. 2019, 297, 126758. [CrossRef]

27. Ludvigsen, M.; Sørensen, A.J. Towards integrated autonomous underwater operations for ocean mapping and monitoring. Annu. Rev. Control 2016, 42, 145-157. [CrossRef]

28. Yu, Y.; He, L.H.; Li, Y.F. Research of ecology monitoring network in China base on GAP technology. Ecol. Sci. 2015, 34, 157-162.

29. Zimmer, B.; Manzello, L.; Madsen, K.; Sinclair, J.; Green, R.E. An innovative ocean planning tool for the Atlantic outer continental shelf: The EcoSpatial Information Database. Mar. Policy 2014, 45, 60-68. [CrossRef]

30. Ravish, S.; Setia, B.; Deswal, S. Monitoring of pre and post-monsoon groundwater quality of north-eastern Haryana region using GIS. Environ. Technol. 2019, 1-27. [CrossRef]

31. Pope, R.; Wu, J. A multi-objective assessment of an air quality monitoring network using environmental, economic, and social indicators and GIS-based models. J. Air Waste Manage. Assoc. 2014, 64, 721-737. [CrossRef] 
32. Deepak, P. Monitoring the Amazon wildfires with satellites, IoT sensors and GIS. Netw. World (Online) 2019, $8,3434517$.

33. Giardina, M.; Buffa, P.; Abita, A.M.; Madonia, G. Fuzzy environmental analogy index to develop environmental similarity maps for designing air quality monitoring networks on a large-scale. Stoch. Environ. Res. Risk Assess. 2019, 33, 1793-1813. [CrossRef]

34. Jeihouni, M.; Toomanian, A.; Alavipanah, S.K.; Hamzeh, S.; Pilesjö, P. Long term groundwater balance and water quality monitoring in the eastern plains of Urmia Lake, Iran: A novel GIS based low cost approach. J. Afr. Earth Sci. 2018, 147, 11-19. [CrossRef]

35. Manandhar, P.; Marpu, P.R.; Aung, Z. Segmentation based traversing-agent approach for road width extraction from satellite images using volunteered geographic information. Appl. Comput. Inform. 2018. [CrossRef]

36. Zhang, J.; Zhang, J.; Du, X.Y.; Kang, H.; Qiao, M.G. An overview of ecological monitoring based on geographic information system (GIS) and remote sensing (RS) technology in China. IOP Conf. Ser. Earth Environ. Sci. 2017, 94, 012056. [CrossRef]

37. $\mathrm{Mu}, \mathrm{F}$; $\mathrm{Wu}, \mathrm{X}$. The water quality emergency monitoring system based on GIS and RS for urban drinking water source. Proceeding of the 2010 2nd International Workshop on Intelligent Systems and Applications, Wuhan, China, 22-23 May 2010; Institute of Electrical and Electronics Engineers: Piscataway, NJ, USA, 2010; pp. 1-4.

38. Md Bohari, N.F.; Kruger, E.; John, J.; Tennant, M. Analysis of dental services distribution in Malaysia: A geographic information systems-based approach. Int. Dent. J. 2019, 69, 223-229. [CrossRef] [PubMed]

39. Radil, S.M. A network approach to the production of geographic context using exponential random graph models. Int. J. Geogr. Inform. Sci. 2019, 33, 1270-1288. [CrossRef]

40. Vaughan, H.; Bydges, T.; French, A.; Lumb, A. Monitoring long-term ecological changes through the Ecological Monitoring and Assessment Network: Science-based and policy relevant. Environ. Monit. Assess. 2001, 67, 3-28. [CrossRef] [PubMed]

41. Haase, P.; Frenzel, M.; Klotz, S.; Musche, M.; Stoll, S. The long-term ecological research (LTER) network: Relevance, current status, future perspective and examples from marine, freshwater and terrestrial long-term observation. Ecol. Indic. 2016, 100, 1-3. [CrossRef]

42. Stoll, S.; Frenzel, M.; Burkhard, B.; Adamescu, M.; Augustaitis, A.; Baeßler, C. Assessment of ecosystem integrity and service gradients across Europe using the LTER Europe network. Ecol. Modell. 2015, 295, 75-87. [CrossRef]

43. Fu, B.; Li, S.; Yu, X.; Yang, P.; Yu, G.; Feng, R.; Zhuang, X. Chinese ecosystem research network: Progress and perspectives. Ecol. Complex. 2010, 7, 225-233. [CrossRef]

44. Knapp, A.K.; Smith, M.D.; Hobbie, S.E.; Collins, S.L.; Fahey, T.J.; Hansen, G.J. Past, present, and future roles of long-term experiments in the LTER network. BioScience 2012, 62, 377-389. [CrossRef]

45. Li, Y.M.; Pan, M.H. Continental strategy of the U.S. national ecological observation network. Adv. Earth Sci. 2008, 11, 1218-1219.

46. $\mathrm{Su}, \mathrm{W}$. Application of long-term observation data of ecosystem observation research network based on bibliometrics. Actecologicasinica 2019, 39, 5005-5013.

47. UK Centre for Ecology \& Hydrology Lancaster Environment Centre. British Environmental Change Network. 2019. Available online: http://www.ecn.ac.uk/what-we-do (accessed on 24 December 2019).

48. Sundareshwar, P.V.; Murtugudde, R.; Srinivasan, G.; Singh, S.; Ramesh, K.J.; Ramesh, R.; Baruah, K.K. Environmental monitoring network for India. Science 2007, 316, 204-205. [CrossRef] [PubMed]

49. Likens, G.E.; Lindenmayer, D.B. A strategic plan for an Australian Long-Term Environmental Monitoring Network. Aust. Ecol. 2011, 36,1-8. [CrossRef]

50. Silva, C.; Quiroz, A. Optimization of the atmospheric pollution monitoring network at Santiago de Chile. Atmos. Environ. 2003, 37, 2337-2345. [CrossRef]

51. Chinese Academy of Sciences. China Ecosystem Research Network. 2019. Available online: http: //www.cern.ac.cn/1wljs/detail.asp?channelid1=100100\&id=6 (accessed on 24 December 2019).

52. Saaty, T.L. What is the analytic hierarchy process? In Mathematical Models for Decision Support; Springer: Berlin, Germany, 1988. 
53. Goetschalckx, M. An interactive layout heuristic based on hexagonal adjaeency graphs. Eur. J. Oper. Res. 1992, 63, 304-321. [CrossRef]

54. Zadeh, L.A. Fuzzy sets. Inform. Control 1965, 8, 338-353. [CrossRef] (CC BY) license (http://creativecommons.org/licenses/by/4.0/). 